\title{
PELUANG PENGINTEGRASIAN DISKURSUS LITERASI MEDIA SEBAGAI MUATAN LOKAL PADA KURIKULUM PENDIDIKAN SEKOLAH DASAR
}

\author{
Ita Musfirowati Hanika, Ilham Ayatullah Syamtar \\ Fakultas Komunikasi dan Diplomasi, Universitas Pertamina, Jakarta. \\ ilhamayatullahs@gmail.com \\ Diajukan: 16-10-2019; Direview: 29-10-2019; Diterima: 22-12-2019;
}

\begin{abstract}
Massive migration of people in the use of new media has a significant impact on the emergence of several social phenomena, especially in school-age children. New media has a positive side if it's used wisely but will have a destructive effect if the users isn't well educated. The schools become an institution that are responsible for changes in children's behavior, including educating children to use new media wisely. This study aims to determine the urgency, opportunities, and obstacles of digital media literacy education discourse for students and educators in elementary schools. Using descriptive qualtitative research, this study uses Bandura's Social Learning Theory to analyze answers from a number of teachers and students in Jakarta who became the sample. The results showed that the digital media literacy discourse has become important to be integrated into the Education curriculum by utilizing considerable opportunities and adjustments to existing regulations.
\end{abstract}

Keywords: New Media Effects, Digital Media Literacy, Social Learning Theory

\begin{abstract}
Abstrak
Migrasi besar-besaran masyarakat dalam penggunaan media baru nyatanya berdampak cukup signifikan terhadap timbulnya beberapa gejala sosial terutama pada anak-anak usia sekolah. Media baru memiliki sisi positif jika digunakan secara bijak namun akan berdampak destruktif jika penggunanya tidak teredukasi dengan baik. Sebagai salah satu pendidikan formal, sekolah menjadi institusi yang bertanggung jawab terhadap perubahan perilaku anak termasuk salah satunya mengedukasi anak-anak untuk menggunakan media baru secara bijak. Berangkat dari permasalahan tersebut, penelitian ini bertujuan untuk mengetahui urgensi, peluang, dan hambatan dari diskursus pendidikan literasi media digital bagi peserta didik maupun tenaga pendidik di sekolah tingkat dasar. Menggunakan penelitian kualitatif deskriptif, penelitian ini menggunakan Teori Belajar Sosial Bandura untuk menganalisa jawaban dari sejumlah guru dan siswa di Jakarta yang menjadi sampel penelitian. Hasil penelitian menunjukkan bahwa diskursus literasi media digital telah sampai menjadi penting untuk diintegrasikan kedalam kurikulum Pendidikan dengan memanfaatkan peluang yang cukup besar dan penyesuaian terhadap regulasi yang ada.
\end{abstract}

Kata Kunci : Efek Media Baru, Literasi Media Digital, Teori Belajar Sosial

\section{PENDAHULUAN}

$\mathrm{E}$ $\mathrm{E}^{\mathrm{m} \text { diripani }}$ perkembangan dan kemajuan teknologi di berbagai bidang, melahirkan sejumlah manfaat dan dampak tersendiri. Salah satu realita yang dilahirkan adalah fakta bahwa informasi telah menjadi komoditas produksi terbesar abad ini. Kapabilitas tersebut memberikan ruang yang nyaris tanpa batas pada masyarakat untuk dapat memperoleh dan menyebarluaskan berbagai informasi di sejumlah kanal media digital, yang pada saat bersamaan juga mendorong timbulnya dampak-dampak mengkhawatirkan, diantaranya: persebaran berita bohong (hoax) dan ujaran kebencian (hate speech); perundungan siber (Cyber-Bullying); pencurian/ penyalahgunaan data pribadi; pornografi dan kekerasan; penculikan, kecanduan; dan seterusnya., terlepas dari seluruh manfaat dan kemudahan yang bisa kita terima.

Marshall McLuhan (1964) lima puluh tahun 
silam dalam bukunya yang berjudul Understanding The Media mengatakan "Kita memang akan mengalami kemajuan dalam teknologi, namun mengalami kemunduran dalam hal budaya (Straubhaar, 2012:49), atau juga pada argumen lainnya yang terkenal "We Shape Our Tools than Our Tools Shape Us" (McLuhan, 1964). Kondisi dilematis tersebut mengafirmasi bahwa interaksi yang terjadi antara masyarakat dan media bukanlah persoalan yang mudah diabaikan, sebab pada gradasi tertentu justru dapat menyebabkan mundurnya kualitas suatu generasi, terlebih pada kelompok usia dini yang menjadi penentu masa depan suatu bangsa dan negara. Asosiasi Penyelenggara Internet Indonesia (APJII) 2016 menunjukkan, pengguna internet di Indonesia sendiri telah mencapai 143,26 juta jiwa, atau setara dengan 54,6\% dari total masyarakat Indonesia, sekitar 35,56 juta jiwanya adalah kelompok usia anak-anak (Syamtar \& Kusuma, 2019). Anak-anak secara otomatis menjadi kelompok paling rentan jika dihadapkan pada kekuatan kuantitas sebesar itu terlebih jika melihat pada rendahnya minat baca masyarakat Indonesia (Damarjati, 2019).

Dewasa ini, kehidupan anak-anak yang begitu erat dengan media menjadikan anak-anak tersebut juga mendapat julukan sebagai generasi screen culture (Generasi Layar) (Nur, 2018 dalam Suwarto, 2018), entah itu layar televisi, komputer, maupun telepon genggam. Mengingat anak-anak merupakan peniru handal, mereka bisa dengan mudah membentuk persepsi terhadap sesuatu dan menginternalisasikan nilai-nilai berdasarkan apa yang mereka lihat dan dengar dari lingkungan sekitarnya. Media bahkan nyaris menggeser peran orangtua dan lingkungan sosial dalam memenuhi kebutuhan interaksi dan komunikasi mereka (Nur, 2018 dalam Suwarto, 2018).

Lemahnya pengawasan orang tua dan rendahnya keterampilan anak untuk memfilterisasi secara mandiri informasi yang ada pada media, tentu memberikan ruang yang luas bagi dampak negatif internet untuk dapat menjangkau anak-anak. Sebut saja video game misalnya, selain mampu mengasah kreatifitas, anak-anak juga berpotensi menirukan konten games yang mengandung kekerasan. Pada kasus yang lebih esktrim, permainan games dapat menyebabkan kecanduan yang dapat berdampak buruk bagi kesehatan fisik dan psikologis anak. Dari segi fisik misalnya, dapat berupa penurunan berat badan yang tidak normal dan terganggunya jadwal istirahat (Hardanti, dkk., 2013). Sementara dari segi psikologis, anak kurang sosialisasi, kurang peka terhadap sekitar, malas mengerjakan PR, sulit konsentrasi pada pelajaran di sekolah, mudah stres saat kalah bermain (Greenfield \& Gross, 2000 dalam Hardanti, dkk., 2013).

Lebih lanjut dengan segala keluasan aksesibilitasnya, internet juga mendekatkan anak pada dunia pornografi yang begitu mudah dijangkau. Anak-anak yang belum sepantasnya melihat materi apapun terkait pornografi dapat dengan mudahnya terpapar. Hal ini dikarenakan para pemilik industri pornografi kerap menggunakan kata kunci yang sangat dekat dengan bahasa anak, seperti Barbie, Nintendo, Mawar, Melati, Disney, Toys, dan sebagainya. Secara tidak sadar anak-anak dapat tersambung kepada saluran-saluran pornografi secara bebas (Hastuti, 2011 dalam Nur 2018).

Pada praktiknya, sebenarnya telah banyak gerakan aktivis literasi yang kiranya berusaha pro-aktif untuk meningkatkan kemampuan literasi digital masyarakat dengan menjadikan anak-anak sebagai target utama sasasaran kampanye. Akan tetapi, Bobi Guntarto (2016) dalam penelitiannya menuturkan bahwa penerapan diskursus literasi media di Indonesia masih menemui kendala karena diskursus literasi media ini masih dianggap sebagai isu yang tidak terlalu mendesak dalam kaca mata pemerintah dibandingkan isu-isu lainnya seperti narkoba, korupsi, kemiskinan, dan isu-isu lainnya. Padahal, berangkat dari realitas sosial yang bergesekan dengan perkembangan teknologi sekarang, masyarakat tidak hanya perlu dibekali kemampuan untuk menggunakan perangkat media yang ada, tetapi juga perlu dibekali pemahaman akan implikasi dari penggunaan perangkatperangkat tersebut.

Sejumlah upaya juga telah dilakukan pemerintah untuk meminimalisir efek yang ditimbulkan dari pemanfaatan media digital seperti filterisasi melalui internet positif, penindakan melalui 
undang-undang ITE, dan pembatasan media sosial dengan cara menutup akses jika diperlukan. Namun, yang mesti disadari oleh berbagai pihak adalah upaya membangun kemampuan selfcensorship 1 self-control sejak dini merupakan hal penting di tengah-tengah masyarakat melalui upaya-upaya literasi media/literasi digital. Sebab pada kenyataannya, regulasi yang dibuat untuk "membentengi" masyarakat dari dampak buruk teknologi, perkembangannya akan selalu selangkah lebih cepat daripada jangkauan pencegahan penggunanya. Oleh sebab itu, benteng terakhir yang seharusnya diandalkan dan dikembangkan adalah kapasitas dari masyarakat untuk dapat menarik garis batas antara aspek positif dan negatif dari perkembangan teknologi yang kian pesat ini secara mandiri dan bertanggung jawab.

Wacana restorasi mata pelajaran Teknologi Informasi dan Komunikasi atau yang lebih dikenal dengan nama TIK di tingkat pendidikan dasar, oleh Kementerian Pendidikan dan Kebudayaan, baru kembali digalakkan awal tahun ini setelah mendapat desakan dari Ikatan Guru TIK Persatuan Guru Republik Indonesia yang menyesalkan penghapusan TIK dari kurikulum pembelajaran sejak tahun 2013 silam. Pemerintah menganggap bahwa TIK dapat dipelajari melalui implementasi di setiap pelajaran lainnya, sehingga tidak membutuhkan pendidikan khusus. Padahal, yang mesti digaris bawahi adalah literasi media bukan hanya persoalan anak-anak mahir "menggunakan" suatu media saja, melainkan juga "memahami" implikasi dari media yang mereka gunakan. Analogi dari hal tersebut digambarkan selayaknya ketika anak-anak bermain pistol mainan, mereka dapat serta-merta mampu menggunakan mainan tersebut lengkap dengan pelurunya tanpa perlu diajarkan, namun bukanlah hal yang mustahil jika pistol mainan yang digunakan juga dapat melukai dirinya sendiri dan bahkan orang lain. Penelitian yang dilakukan oleh Mulyono dan Halim (2015) juga sejalan dengan hal tersebut, bahwa dunia pendidikan khususnya sekolah saat ini masih

1 Dalam konteks efek negatif media, self-censorship diartikan sebagai kapasitas atau kemampuan untuk menentukan keinginan dan intensi yang efektif terhadap perilaku kita, terlepas dari gangguan dan pengaruh eksternal (Bermudez, 2016). bertumpu pada akses terhadap informasi dan kemampuan peserta didik dalam menggunakan perangkat teknologi TIK, belum menyentuh aspek pengetahuan akan implikasi dari penggunaan perangkat teknologi tersebut.

Oleh karenanya, terlepas dari peran orangtua sebagai institusi pertama yang memiliki tanggung jawab untuk mendidik anak seputar penggunaan media, sekolah tetap punya andil yang begitu besar untuk membantu atau setidaknya menekan dampak buruk dari perkembangan teknologi ini dengan membekali anak-anak kemampuan literasi dengan pendekatan yang sesuai dengan mereka. Sayangnya, berdasarkan temuan dari penelitian yang dilakukan Retno Manuhoro Setyowati (2013) di tataran sekolah PAUD misalnya, menunjukkan bahwa masih sulitnya menemui guru yang melek media nyatanya turut berkontribusi menjadi kendala yang cukup besar dalam pelaksanaan upaya literasi media di sekolah. Terlebih lagi, masih banyak sekolah yang menganggap bahwa literasi media bukanlah sesuatu yang terlalu penting untuk diperhatikan. Padahal literasi media di sekolah bukanlah sesuatu yang terlalu berlebihan untuk diwujudkan, sebab anak-anak menghabiskan sebagian besar waktu mereka di sekolah. Sekolah sebagai institusi pendidikan formal tentu lebih mudah dijangkau dan dievaluasi kegiatannya dalam upaya-upaya berkaitan dengan literasi media kepada anak-anak.

Sehingga, berangkat dari permasalahan tersebut, penelitian kali ini difokuskan pada tinjauan terhadap regulasi yang ada dan persepsi guru mengenai diskursus literasi media, guna melihat urgensi dari diskursus literasi media dalam pandangan tenaga pendidik, serta peluang dan faktor apa saja yang sebenarnya menghambat pengimplementasian literasi media digital secara sistemik ke dalam kurikulum pendidikan khususnya pada tingkatan sekolah dasar. Hasil penelitian ini diproyeksikan dapat memberikan gambaran mengenai peluang pengimplementasian literasi media pada tingkatan sekolah dasar, sehingga dapat mendorong disusunnya suatu bentuk/model yang lebih spesifik lagi di masa mendatang. 


\section{LITERATUR DAN METODOLOGI}

\section{Media Literacy}

Kemampuan literasi media muncul seiring dengan berkembangnya teknologi media yang membawa pengaruh bagi individu dan juga masyarakat umum. Tingkat kemampuan literasi media dapat dilihat dari kemampuan berpikir kritis para pengguna media dalam mengartikan pesan yang ada di media dan juga memanfaatkan informasi tersebut untuk membawa kebaikan bagi diri mereka.

Terdapat 7 (tujuh) kemampuan literasi media untuk melihat pola perilaku individu dalam memahami media dan isi pesan yang disampaikan, yaitu: Pertama, Kemampuan untuk menganalisa yang terkait dengan pengetahuan individu dalam memahami pesan medial; Kedua, Kemampuan melakukan evaluasi atau penilaian terhadap informasi yang ada di media untuk memenuhi kebutuhan diri; Ketiga, Kemampuan melakukan pengelompokkan yang terkait dengan menentukan komponen yang sama ke dalam kelompok informasi tertentu; Keempat, Kemampuan dalam menarik simpulan dari informasi yang ada di media sehingga membentuk pola tertentu; Kelima, Kemampuan melakukan sintesa yang dilihat dengan kebiasaan individu dalam membangun konstruksi pesan ke struktur baru; Keenam, Kemampuan abstraksi yang dapat dilihat dari kemampuan individu menerjemahkan pesan dan yang Ketujuh adalah untuk mengartikan tujuan dari pesan yang disampaikan di media (Potter, 2008).

\section{Social Learning Theory}

Guna memahami perubahan individu yang disebabkan oleh media terutama media digital terdapat sejumlah faktor yaitu faktor internal yang berasal dari dalam individu dan faktor eksternal seperti lingkungan. Lebih lanjut komponen ketiganya dijelaskan melalui Teori Belajar Sosial yang dikemukakan oleh Bandura (dalam Schunk, 2012). Secara ringkas, Bandura (dalam Schunk, 2012) menyatakan bahwa untuk memahami Teori Belajar Sosial terdapat sejumlah asumsi mendasar tentang pembelajaran dan perilaku. Asumsi ini membicarakan tentang interaksi timbal-balik antar manusia, perilaku, dan lingkungan; pembelajaran melalui praktik dan melalui pengamatan dalam hal ini memahami proses pembelajaran terjadi. Teori Belajar Sosial tidak hanya melihat karakter perilaku individu yang tampak namun juga melihat pada aspek kognisi seperti memori, motivasi, dan aspek kecerdasan.

\section{Metodologi}

Penelitian ini merupakan penelitian deskriptif kualitatif dengan metode studi kasus. Adapun untuk mendapatkan hasil dari permasalahan yang ada, peneliti menggunakan in-depth interview yang dimaksudkan untuk menggali persepsi terhadap suatu program, peristiwa, dan aktivitas dari subyek yang diteliti (Rahardjo, 2017). Narasumber diberikan pertanyaan menyangkut hal-hal yang berkaitan dengan pengetahuan mereka mengenai literasi media, regulasi sekolah terhadap literasi media dan hambatannya, serta aktivitas apa saja yang mereka lakukan selama ini menyangkut literasi media di kelas. Narasumber berasal dari dua orang guru dari SD Muhammadiyah 28 Jakarta dan SD Kebayoran Lama Selatan 11 Pagi.

Sebagai perbandingan dari jawaban yang diberikan narasumber, disebarkan pula survei kepada sejumlah siswa di kedua sekolah tersebut yang jumlahnya sebanyak 48 orang. Pertanyaan survei dikaitkan dengan tahap-tahapan kemampuan literasi media sebagaimana yang dikemukakan oleh Potter (2008) pada bagian sebelumnya, menyangkut kemampuan mengakses, menganalisa, mengevaluasi, mengoperasikan, dan mengomunikasikan media yang digunakan. Dengan begitu, peneliti dapat melihat permasalahan secara lebih luas dan menyeluruh.

\section{TEMUAN DAN DISKUSI}

Literasi media digital menjadi isu signifikan yang seringkali dibahas para pegiat literasi media dan juga para akademisi mengingat masifnya perkembangan teknologi. Secara ideal pendidikan literasi media harus dilakukan secara bersamasama antar berbagai pihak sebagaimana yang 
disampaikan oleh Hendriyani \& Guntarto (2011), setidaknya terdapat 5 (Lima) kategori kelompok utama yang sejauh ini telah turut andil dalam berbagai kegiatan kampanye literasi media secara mandiri. Pertama, kategori LSM dan Yayasan yang memiliki bidang pekerjaan terkait dengan kegiatan pemberdayaan masyarakat berupa pelatihan, seminar, dan pendampingan. Kedua, kelompok yang berasal dari perguruan tertinggi, khususnya program studi Ilmu Komunikasi yang memang mendalami diskursus ini. Ketiga, berasal dari kelompok masyarakat umum yang aktif mengembangkan literasi media di lingkungan mereka sendiri, seperti beberapa desa di Sleman dan Solo yang menerapkan jam khusus untuk tidak menyalakan televisi saat waktu belajar anakanak. Keempat, kelompok yang mengatur regulasi, yakni pemerintah, melalui Dewan Pers, Komisi Penyiaran Indonesia (KPI), dan sebagainya. Kelima, kelompok yang merupakan gabungan dari berbagai lembaga, seperti Koalisi Kampanye Hari Tanpa TV (2006-2011). Terakhir, sekolah yang menjadi sasaran dan traget bagi pengembangan pendidikan literasi media (Suwarto, 2018).

Sebagai pihak yang menjadi sasaran bagi pengembangan pendidikan literasi media, sekolah menjadi sarana efektif untuk mengintegrasikan literasi media dalam kurikulum pendidikan di Indonesia terlebih dengan adanya peraturat pemerintah dalam Permendikbud No. 36 dan 37 Tahun 2018 menyangkut mata pelajaran seputar media pada tingkat SD hingga SMA sederajat. Hal ini tentu menjadi angin segar yang ditunggutunggu oleh para pegiat literasi yang memang lebih didominasi oleh komunitas-komunitas dan LSM mandiri karena peraturan ini diproyeksikan akan memberikan ruang seluas-luasnya bagi sekolah sebagai Institusi Formal untuk turut membantu memabangun literasi media kepada anak-anak secara sistemik dan komprehensif.

Namun hasil penelitian yang melibatkan 2 (dua) narasumber yakni TH (30 Tahun) selaku guru SD Muhammadiyah 28 Jakarta dan WN (48 Tahun) selaku guru SDN Kebayoran Selatan 11 Pagi, mengakui bahwa implementasi literasi media di tingkat pendidikan dasar belum menyentuh pada pengintegrasian literasi media digital kedalam kurikulum dan masih terbatas pada pemanfaatan teknologi pada kegiatan belajar mengajar seperti menggunakan berbagai sumber dari internet untuk pengayaan materi, penggunaan media pembelajaran digital untuk menciptakan kegiatan interaktif. TH juga melihat, anak-anak jadi memiliki wawasan yang lebih luas dan kemudahan dalam mengerjakan tugas karena kemudahan mengakses informasi melalui internet. Hal yang sama juga dilakukan oleh WN, dalam kesempatan pembelajaran mengenai pelabuhan di setiap provinsi misalnya, WN cukup mencari/browsing seputar nama-nama pelabuhan di setiap provinsi kemudian menayangkan gambar-gambar tersebut melalui LCD di kelas. Cara ini menurutnya lebih efektif ketimbang harus mengajak anak-anak untuk memperhatikan atlas di perpustakaan yang tentu memakan banyak waktu dan tidak begitu mendetail. Seperti disampaikan oleh Felder-Silverman dalam teori Learning Style Model bahwa salah satu dimensi belajar, menyinggung pula aspek input visual (Widianingrum, D.L. \& Ho, H.C., 2015). Anak-anak yang juga tumbuh berbarengan dengan perkembangan teknologi visual, tentu menikmati dan terbiasa terhadap berbagai efek visual.

Padahal seperti yang disampaikan di bab sebelumnya, bahwa kemampuan literasi media kemampuan literasi media digital tidak hanya terbatas pada kemampuan individu menggunakan teknologi namun lebih kepada memahami media dan menginterpretasikan isi pesan dengan mengacu pada 7 (tujuh) kemampuan literasi media untuk melihat pola perilaku individu dalam memahami media dan isi pesan yang disampaikan, yaitu: Pertama, Kemampuan untuk menganalisa yang terkait dengan pengetahuan individu dalam memahami pesan medial; Kedua, Kemampuan melakukan evaluasi atau penilaian terhadap informasi yang ada di media untuk memenuhi kebutuhan diri; Ketiga, Kemampuan melakukan pengelompokkan yang terkait dengan menentukan komponen yang sama ke dalam kelompok informasi tertentu; Keempat, Kemampuan dalam menarik simpulan dari informasi yang ada di media sehingga membentuk pola tertentu; Kelima, 
Kemampuan melakukan sintesa yang dilihat dengan kebiasaan individu dalam membangun konstruksi pesan ke struktur baru; Keenam, Kemampuan abstraksi yang dapat dilihat dari kemampuan individu menerjemahkan pesan dan mengartikan tujuan dari pesan yang disampaikan di media (Potter, 2008).

\section{Tingkat Kemampuan Literasi Media Siswa}

Hasil survei yang dibagikan kepada siswa di kedua sekolah mendapati hasil bahwa 95\% siswa sudah memiliki 2 (dua) kemampuan dari 7 (tujuh) kemampuan literasi media yang disebutkan oleh Potter (2008) yaitu kemampuan untuk menganalisa yang terkait dengan pengetahuan individu dalam memahami pesan media dan kemampuan melakukan evaluasi atau penilaian terhadap informasi yang ada di media untuk memenuhi kebutuhan diri. Meskipun mereka mengetahui cara menggunakan media sosial dan sering menonton YouTube namun mayoritas siswa menyatakan bahwa tidak ada semua yang ada di internet baik untuk dikonsumsi dan tidak semua video di YouTube merupakan konten yang layak tonton. Dari segi kemampuan evaluasi, para siswa juga memahami bahwa kehadiran media digital dapat mendukung mereka dalam mencari informasi yang sesuai dengan kebutuhan mereka seperti informasi yang tersebar di sejumlah website untuk membantu mereka mengerjakan tugas rumah, membaca berita, membantu mengerjakan tugas, berkomunikasi dengan teman, dan hiburan dengan cara menonton video lucu di YouTube.

Selain manfaat yang didapatkan, mereka juga memahami bahaya yang mengintai dari penggunaan media digital secara berlebihan yaitu terganggunya waktu belajar dan waktu tidur, merusak kesehatan fisik seperti mata. Guna menjaga kesehatan para siswa, mereka mengatakan bahwa batas wajar penggunaan media digital dalam sehari tidak boleh lebih dari 2 (dua) jam. Lebih lanjut, para siswa juga mengetahui tata cara dalam menggunakan media sosial seperti tidak boleh mengikuti akun yang tidak dikenal atau orang asing, tidak boleh mengunggah informasi yang bersifat pibadi untuk usia mereka, tidak boleh melakukan perundungan di media sosial atau berkomentar dengan kata-kata yang jahat dan mengganggu orang yang memiliki akun. Selain hal tersebut, para siswa juga sepakat bahwa individu yang leluasa mengambil foto orang lain tanpa izin dan mengunggah di media sosial merupakan bentuk tidak terpuji.

Jika melihat pada hasil survei tersebut, maka kemampuan literasi media digital para siswa termasuk tinggi untuk anak seusia mereka mengingat mereka sudah memahami dengan baik manfaat dan dampak buruk dari media digital dan tidak langsung mempercayai pesan yang ditampilkan di media tersebut. Potter (2018) menjelaskan bahwa individu yang memiliki tingkat literasi media yang rendah hanya memahami isi pesan berdasarkan konstruksi yang dibangun dari yang dilihat oleh penggunanya sedangkan bagi individu yang memiliki tingkat literasi media yang tinggi dapat mengkonstruksi pesan secara berbeda dari yang ditampilkan oleh media.

Hal ini menjadi menarik karena data lain justru menjelaskan bahwa sebagian besar orang tua tidak mendampingi mereka ketika menggunakan media, sementara di kedua sekolah tempat responden mengenyam pendidikan justru belum terdapat program yang mengkhususkan literasi media sebagai bahan pembelajaran. Analisa terhadap pencapaian atas pengetahuan tersebut didapatkan dari pengawasan orangtua, peran guru di sekolah, dan juga kemampuan mandiri individu dalam menilai. Dalam hal pengawasan orangtua, meskipun hasil survei mendapati hasil bahwa orangtua tidak mendampingi anak saat mengakses media digital, namun menurut jawaban survei, para siswa dilarang menggunakan perangkat teknologi terlalu lama. Kedua, meskipun secara tidak sadar guru sudah mengajarkan literasi media digital di sekolah namun para siswa mengungkapkan bahwa guru juga memiliki peran yang sangat besar terutama dalam mengajarkan informasi yang layak untuk dijadikan rujukan dan tidak serta situs yang layak untuk dikunjungi. Terakhir, anakanak mengetahui sendiri hal tersebut berdasarkan kemampuan mereka sendiri untuk menilai. Hal ini sejalan dengan asumsi teori kognitif sosial bahwa sebagian besar pembelajaran manusia terjadi dalam 
sebuah lingkungan sosial yang memungkinkan terjadinya interaksi timbal balik antara perilaku, variabel lingkungan, dan faktor sosial (Bandura, 1986:50). Tingkat kemampuan individu dalam memahami literasi media digital merupakan manifestasi dari peran orangtua dan guru.

\section{Peluang Pengintegrasian Literasi Media di Sekolah Dasar}

Menyambut peluang besar tersebut, seharusnya kedua sekolah dapat mengembangkan lebih lanjut pendidikan literasi media digital mengingat pengetahuan para siswa yang sudah cukup baik dalam memahami literasi media digital. Terlebih dengan adanya aturan Permendikbud No. 36 dan 37 Tahun 2018, sekolah diberikan kebebasan untuk mengembangkan mata pelajaran seputar media sehingga melalui pemahaman tersebut maka seharusnya hal ini dapat dijadikan peluang untuk implementasi pendidikan literasi media digital yang dapat diintegrasikan kedalam kurikulum pendidikan sekolah dasar setidaknya dalam dua bentuk, yakni sebagai alat bantu pengajaran atau menjadi ekstrakurikuler/muatan lokal di sekolah. Aturan ini sebenarnya memberikan keleluasaan bagi para guru untuk dapat menyesuaikan metode yang dianggap cocok untuk memberikan edukasi mengenai literasi media sesuai dengan karakteristik dari siswa yang dihadapi.

Meskipun kedua sekolah belum memiliki model pengembangan terstruktur mengenai penerapan literasi media digital, namun kedua sekolah menyepakati bahwa kemudahan aksesibilitas siswa terhadap media digital dapat meningkatkan risiko siswa pada pemahaman pesan yang didapatkan dari media digital. Jika individu di satu sisi dapat menggunakan teknologi untuk mendukung pembalajaran, bukan tidak mungkin adanya dampak buruk yang ada dari penggunaan media. Sehingga kedua narasumber menyepakati bahwa sekolah memang perlu untuk mengambil bagian dalam kegiatan literasi media digital.

Terlepas dari keinginan kedua narasumber untuk mengintegrasikan literasi media digital kedalam kurikulum pendidikan, kedua narasumber menyampaikan bahwa mereka juga belum memiliki pemahaman mendalam seputar literasi media digital meskipun dalam sejumlah sesi wawancara dan hasil survei siswa didapati simpulan bahwa mereka sebetulnya sudah memiliki pemahaman mendasar mengenai literasi media digital dan mengajarkannya kepada para siswa yang dibuktikan dengan adanya arahan dari para guru kepada siswa. Meskipun kedua sekolah memiliki regulasi berbeda dalam penggunaan gawai di sekolah yang mana SDN Kebayoran Selatan 11 Pagi memperbolehkan para siswa membawa gawai sedangkan di SD Muhammadiyah 28 Jakarta memberlakukan aturan sebaliknya, namun kedua sekolah sama-sama dianggap memiliki peranan besar bagi tingkat kemampuan literasi media digital siswa yang dianggap sudah cukup baik.

Mengingat SDN Kebayoran Selatan 11 Pagi memiliki regulasi khusus dalam mengatur penggunaan gawai maka para guru diberikan kebebasan untuk memanfaatkan teknologi dalam kegiatan belajar mengajar seperti WN dalam memberikan tugas kepada siswa mengharuskan mereka tidak hanya membaca dari satu sumber tapi dari berbagai sumber yang terpercaya. Selain hal tersebut, WN juga seringkali mengingatkan ketika mata pelajaran tertentu mengharuskan siswa menggunakan gawai atau komputer dalam belajar, maka situs yang dibuka harus yang terkait dengan pelajaran yang diajarkan. Bahkan WN mengungkapkan bahwa karena para siswa sudah terbiasa mencari informasi yang layak maka sejumlah siswa terkadang menjadi tutor sebaya bagi teman-temannya bahkan tidak jarang para guru memberi tugas tanpa menjelaskan materi lebih lanjut karena kemandirian siswa. Jika ada pekerjaan rumah yang mengharuskan siswa mengerjakan secara mandiri maka WN selalu mengarahkan agar siswa dapat menggunakan waktu secara efektif dalam menggunakan teknologi agar tehindar dari paparan radiasi dan terganggunya kesehatan mereka. Sama halnya seperti TH (30 Tahun) selaku guru SD Muhammadiyah 28 Jakarta juga sering mengingatkan agar tidak lama menggunakan perangkat teknologi karena dapat mengganggu kesehatan para siswa dan TH selalu mengarahkan agar para siswa dapat membuka situs atau tayangan 
yang sesuai dengan usia mereka.

Dari hal tersebut bisa dipahami meskipun wadah pengembangan literasi media digital belum secara resmi berjalan dan pengetahuan para guru mengenai literasi media digital masih dirasa kurang namun para guru bertanggung jawab secara moral untuk memiliki peranan aktif dalam mendiseminasikan informasi yang terkait dengan literasi media digital. Selain itu, adanya peluang untuk mengembangkan literasi media digital dengan memanfaatkan siswa yang dianggap unggul dan dapat menjadi tutor sebaya bagi rekan sesamanya.

\section{Sinergi Perguruan Tinggi dan Sekolah}

Mengingat kemampuan literasi media digital para guru masih dirasa kurang, kedua narasumber mengharapkan adanya sinergi antara sekolah, pemerintah, perguruan tinggi, dan orangtua siswa. Dalam hal sinergi sekolah dengan perguruan tinggi, kedua narasumber mengharapkan adanya upaya perguruan tinggi untuk melibatkan sekolah secara aktif dalam kegiatan pengembangan literasi media digital di sekolah dasar. WN menyebutkan bahwa selama ini sekolah hanya sebatas menjadi khalayak sasaran dan belum menjadi aktor utama dalam mengembangkan pendidikan literasi media digital. Selama ini perguruan tinggi hanya menjalankan kegiatan pengabdian masyarakat atau kampanye dalam bentuk peningkatan awareness tanpa adanya pelibatan secara aktif sekolah dalam mengimplementasikan literasi media digital atau keberlanjutan dari kampanye yang telah dilakukan. Perguruan tinggi sebaiknya dapat memberikan edukasi secara berkala dan terstruktur baik kepada guru maupun siswa yang mengedepankan pembelajaran sepanjang hayat sehingga guru dapat belajar secara mandiri dan dapat meneruskan kepada siswa dan para siswa dapat meneruskan kembali kepada rekan sebaya mereka.

Padahal, dalam beberapa kegiatan literasi media di beberapa sekolah dasar di Malang, Jawa Timur misalnya, menunjukkan bahwa guru merupakan aktor utama yang sangat berpengaruh dalam upaya literasi media bagi anak-anak didik mereka (Hendriyani \& Guntarto, 2018 dalam Suwarto,
2018). Sehingga jika guru tidak memahami informasi yang disampaikan kepada peserta didik, maka besar kemungkinan pengembangan literasi media digital ke dalam pendidikan tingkat dasar hanya akan menjadi wacana semata.

\section{Sinergi Pemerintah dan Sekolah}

Selain pada pengembangan diri guru dalam kemampuan literasi media digital yang melibatkan sinergi perguruan tinggi dan juga sekolah, kedua narasumber juga menyatakan bahwa seharusnya pemerintah juga memiliki aturan yang jelas tentang penggunaan media digital di sekolah dan adanya pelajaran mengenai literasi media yang dimasukan dalam mata pelajaran tertentu jika belum memungkinkan membuat satu mata pelajaran tersendiri dan menyediakan fasilitas yang mudah diakses oleh guru dan orang tua murid misalkan dengan menyediakan platform yang memungkinkan guru dan orang tua mengakses sumber bacaan atau berita yang informatif dan meningkatkan pengetahuan mereka dan isu terbaru terkait dengan literasi media digital. WN dan TH juga mengungkapkan jika pemerintah dapat memberikan workshop atau sosialisasi secara berkala misalkan dengan menghadirkan kementerian tertentu untuk membahas isu terkini seperti hoax, hatespeech, cyberbullying, dan lain sebagainya.

\section{Sinergi Orang Tua dan Sekolah}

Terakhir keterlibatan orangtua secara aktif dalam mengawasi siswa menggunakan media digital dirasa penting bagi kedua narasumber. WN menyampaikan bahwa edukasi literasi media digital yang hanya dilakukan oleh sekolah dan minimnya keterlibatan orangtua yang ditandai dengan ketiadaan dukungan atau upaya pendampingan siswa ketika menggunakan media digital maka pelaksanaan literasi media digital tidak akan berjalan secara efektif. WN mengungkapkan akan lebih baik jika orangtua juga diberikan edukasi mengenai literasi media digital misalkan saat pembagian rapot dengan aktifitas yang meningkatkan hubungan orangtua dan anak 
pada saat kampanye berlangsung.

WN dan TH mengatakan bahwa saat ini perputaran informasi di internet sangatlah bebas dan orangtua maupun guru tidak bisa membatasi dan melarang konten layak tonton atau baca atau tidak layak namun yang mereka bisa lakukan sejauh ini hanya mengarahkan para siswa bahwa gawai merupakan produk teknologi yang dapat membawa manfaat bagi kehidupan mereka jika mereka menggunakannya dengan bijakasana. Kedua sekolah sepakat bahwa sinergi sejumlah pihak juga menjadi penting untuk menyambut peluang siswa yang memiliki kemampuan literasi media digital yang sudah cukup baik sehingga pengintegrasian literasi media digital kedalam kurikulum akan sangat dimungkinkan. Jika sekolah sudah memiliki pemahaman dan kertampilan literasi media digital yang mumpuni maka sekolah dapat mengembangkan media pembelajaran yang dapat mendukung edukasi literasi media digital.

Seperti pernyataan yang disampaikan oleh $\mathrm{TH}$, jika para guru sudah memiliki pemahaman mengenai literasi media digital maka guru akan lebih mudah dalam menyiapkan metode pembelajaran yang tepat dalam menyampaikan materi literasi media digital kepada siswa misalkan dengan menggunakan figure atau idola yang disukai oleh siswa sehingga mereka jauh lebih tertarik dan terpengaruh.

\section{SIMPULAN}

Berdasarkan penelitian yang telah dilakukan, dapat diambil kesimpulan bahwa peluang pengintegrasian literasi media ke dalam kurikulum pendidikan setingkat sekolah dasar ternyata sangatlah memungkinkan, bahakan peluang tersebut terbuka lebar dengan adanya aturan baru dari pemerintah menyangkut mata pelajaran TIK di sekolah. Hanya saja, memang perlu kerjasama dari berbagai stakeholder guna menyusun atau mengkreasikan konsep yang tepat agar diskursus literasi media memiliki kesesuaian dengan karakteristik peserta didik yang memiliki aspek psikografis yang berbeda-beda. Adanya mata pelajaran muatan lokal di sekolah dasar juga memberikan ruang kesempatan untuk diskursus literasi media ini diintegrasikan ke dalam kurikulum pendidikan sekolah dasar. Selain itu, dampak buruk media digital yang mengancam anak-anak juga menjadi alasan mendasar mengapa diskursus ini menjadi hal yang begitu penting untuk diwujudkan. Sekolah sebagai bagian penting dari pendidikan anak juga perlu mengambil bagian penting dalam upaya ini. Adapun rekomendasi untuk penelitian selanjutnya, diharapkan dapat mengkaji lebih dalam lagi dari sisi anak-anak sebagai subyek yang dianggap paling rentan, apa-apa saja faktor yang membuat mereka menjadi tahu ataupun tidak tahu segala hal yang menyangkut literasi media, agar jika literasi media ini benar-benar dikonsepkan dan diintegrasikan kedalam kurikulum pendidikan, strukturnya jadi lebih efektif bagi peserta didik.

\section{DAFTAR PUSTAKA}

Bandura, A. (1986). Social Foundations of Thought and Action: A Social Cognitive Theory. Englewood Cliffs. NJ: Prentice Hall

Bermudez, Juan Pablo. (2016). Social Media and Self-Control: The Vices and Virtues of Attention. Externado University of Colombia. Diakses melalui: https://www. researchgate.net/publication/332750164 Self-Censorship

Damarjati, Dani. (2019, Januari 5). Benarkah Minat Baca Orang Indonesia Serendah Ini?. Detik.com. Diakses melalui: https://news. detik.com/berita/d-4371993/benarkahminat-baca-orang-indonesia-serendah-ini

Elia, Stephani. (2017, Oktober 4). 41 Persen Remaja Indonesia Pernah Alami Cyber- Bullying. Kumparan.com. Diakses melalui: https:// kumparan.com/@kumparanstyle/41persen-remaja indonesia-pernah alamicyberbullying

Guntarto, B. (2016). Tantangan dalam Kegiatan Literasi Media di Indonesia. Jurnal UltimaComm, 8(1), 1-36. Diakses melalui: https://www.researchgate.net/ publication/336835482 Tantangan dalam_Kegiatan_Literasi_Media_di_ Indonesia. 
Hamzah, Radja Erland. (2015). Pengunaan Media Sosial Di Kampus dalam Mendukung Pembelajaran Pendidikan. Wacana: Jurnal Ilmiah Ilmu Komunikasi, 14(1), 45-70. Diakses melalui: http://journal.moestopo. ac.id/index.php/wacana/article/view/89/43

Hardanti, H. A. et al. (2013). Faktor-faktor yang Melatarbelakangi Perilaku Adiksi Bermain Game Online pada Anak Usia Sekolah. Vol. 1 Universitas Padjadjaran.

McLuhan, Marshall \& Lapham, L.H. 1964. Understanding Media : The Extensions of Man. MIT Press.

Mulyono, H \& Halim, N. (2015). Literasi Informasi dan Kritis: Urgensi, Perspektif Islam, dan Integrasi. Jurnal Tarbiyah, vol. XXII no.2 Juli-Desember 2015. Diakses melalui :https://www.researchgate.net/ publication/311495059_LITERASI INFORMASI_DAN_KRITIS_Urgensi_ Perspektif_Islam_dan_Integrasi_dalam_ Kurikulum_Pendidikan

Poskotanews. (2019, April 6). Melalui Internet, Sepanjang 2018 ada 2.536 Kasus Paparan Pornografi pada Anak. Poskotanews.com. Diakses melalui: http://poskotanews. com/2019/02/17/melalui-internetsepanjang-2018-ada-2-536- kasuspaparan-pornografi-pada-anak/

Rahardjo, M. (2017). Studi Kasus Dalam Penelitian Kualitatif. UIN Maulana Malik Ibrahim, Malang, Indonesia. Diakses melalui: https:// core.ac.uk/download/pdf/80816930.pdf

Rudiantara. (2016, Desember 29). Ada 800
Ribu Situs Penyebar Hoax di Indonesia. CNN Indonesia. Diakses melalui: https://www.cnnindonesia.com/ teknologi/20161229170130-185-182956/ ada 800-ribu-situs-penyebar-hoax-diindonesia

Schunk, H. Dale. 2012. Learning Theories: an Educational Perspective. Jakarta: Pustaka Pelajar

Setyowati, Retno Manuhoro. (2013). Memahami Pengalaman Literasi Media Guru PAUD Studi Kasus pada Gugus Matahari Kecamatan Bandungan, Kabupaten Semarang. Interaksi: Jurnal Ilmu Komunikasi, vol. 2, no 1, pp. 22-29, Jan. 2013. DOI : https://doi.org/10.14710/ interaksi.2.1.22-29

Straubhaar, J. 2012. Media Now. Boston: Wadsworth.

Suwarto, Dyna Herlina. 2018. Gerakan Literasi Media di Indonesia. Yogyakarta: Rumah Sinema.

Syamtar, I. A., \& Kusuma, K. L. A. (2019). Literasi Media: Upaya Reformasi untuk bahtera yang Usang. Program Studi Ilmu Komunikasi, Universitas Pertamina, Jakarta.

Widianingrum, D.L. \& Ho, H.C. (2015). FelderSilverman Learning Style Model and The Relationship with Academic Performance. ANIMA Indonesian Phsycologhical Journal. DOI: https://doi.org/10.24123/ aipj.v30i2.538 